\title{
Physico-chemical and Sensory Properties of Ready-To-Cook Milk based Snack "Milk Crisp"
}

\author{
Bhujendra Soni*, Geeta Chauhan, S.K. Mendiratta and Subhashis Mohapatra
}

Division of Livestock Product Technology, Indian Veterinary Research Institute, Izatnagar, Bareilly-243122, Uttar Pradesh, India

*Corresponding author

\section{A B S T R A C T}

Keywords

Sensory evaluation, milk crisp, Readyto-cook milk based snack (RTCMBS),

Skim milk coagulum

Article Info

Accepted:

22 June 2020

Available Online:

10 July 2020
A study was planned to develop ready-to-cook milk based snack "Milk Crisp" by incorporating optimum level of cereals (rice and wheat) and legume based ( green gram and black gram ) flour to evaluate their quality attributes. Incorporation of legume based flour did not show significant $(\mathrm{P}<0.05)$ change in $\mathrm{pH}$, but yield increased significantly $(\mathrm{P}<0.05)$. There was a significant $(\mathrm{P}<0.05)$ decrease in moisture, fat, protein content and gross energy as level of skim milk coagulum decreases in the treatments but carbohydrate and ash content increased in the green gram based products. Significant $(\mathrm{P}<0.05)$ improvement in the sensory attributes of milk crisp was noticed by addition of legume flours. Incorporation of green gram resulted in significant $(\mathrm{P}<0.05)$ increase in expansion percentage, percentage oil uptake and colour value/ yellowness however, significant $(\mathrm{P}<0.05)$ reduction in shear force value.

\section{Introduction}

The snacks available in the market are mainly cereal based which are high in carbohydrates and low in protein contents. However, the delivery of nutrition via incorporation of milk in ready-to-eat expanded snacks is a relatively new concept and is motivated mainly by health concerns. The most effective means of achieving this is via the process of extrusion, a continuous cooking and puffing technology that have gained widespread use in the last several decades for the production of a variety of expanded snacks and breakfast cereals (Trater et al., 2005). So, to impart nutritive value to these snacks particularly in the form of protein, addition of milk is a revolutionary step. Eating of such snacks may provide a balanced food in terms of nutritive value and are much preferred by the children and growing population due to their crispy and tasty nature, along with its variety of options 
which satisfy the satiety centre easily (Singh et al., 2011).

India is the largest milk producing country in the world with estimated production of 116.0 million tons (Bhasin, 2010). This dairy stream also represents an excellent source of functional proteins, peptides, lipids, vitamins, minerals, and lactose, which have been recognized only relatively recently (Smithers, 2008; Abd El-Salam et al., 2009 and Madureira et al., 2010). The major portion of milk is converted into traditional dairy products like paneer and paneer-based products, chhana and chhana-based products, khoa and khoa-based sweets and desserts, which are deep rooted in ancient traditions and have a strong cultural heritage. In recent years, dairy industry has been diversifying its production portfolio to include the specialty foods that cater to specific targeted populations. Milk proteins are the most valuable leading component of milk and are often commercialized in a dehydrated form to extend their shelf-life, facilitate their use and reduce transportation costs. There play a range of valuable roles regarding nutrition and physical functionality. Furthermore, their use under controlled conditions to produce nutritional, functional or flavorful dairy products and occasionally biological activities was often demonstrated (Sawyer et al., 2002). Onwulata et al., (2001, 2003) successfully incorporated whey protein into snack products to increase the protein content (up to 20\%) and extend the nutritive value.

Snack food is one of the fastest growing segments of the food industry (Brower, 2002). The reported growth of the market of snacks is due to their low carbohydrate, fat content and diverse flavor selection (Bosse and Boland, 2008). Snacks being convenient fast food items, contribute towards the nutrition as well as calorie intake of consumers (Tettweiler, 1991). Srinivasan (2000) developed the mini snacks containing cheese powder to create a novel taste and studied its quality characteristics. Cheese powder was added to black gram flour at $0-50$ per cent levels and snacks were prepared and deep fat fried at $180^{\circ} \mathrm{C}$. Up to 20 per cent addition of cheese powder gave no perceptible change in taste or flavour of the mini snack. At 30 per cent addition brown colouration was observed which decreased the sensory appeal. At 40 and 50 per cent levels, although the mouth feel and flavour of cheese was desirable, browning increased markedly, which drastically lowered the overall acceptability. Ascorbic acid addition at 0.5-1.0 per cent markedly decreased the browning. Shurpalekar et al., (1975) conducted a study on snack based blends of cereal, pulse and starch like rice, wheat, horse gram, gelatinized starch in the form of rice gruel. Pre gelatinized starch that maintain their granular shape improve the handling and forming properties of the dough used to make expanded products (Huang, 2000). Effects of the addition of green gram flour and sodium bicarbonate to wheat and rice flour on pasting properties and quality of snacks was investigated by Singh et al., (1996). Blending of green gram flour and addition of sodium bicarbonate significantly increased the gelatinization temperature, but reduced the viscosity. The textural quality of snacks significantly increased due to the addition of sodium bicarbonate. Green gram flour blended with wheat or rice flour, resulted in darker colour snack, which was further enhanced by the addition of sodium bicarbonate. All the quality attributes showed further deterioration on the addition of sodium bicarbonate. The addition of sodium bicarbonate at 0.5 per cent level had a negative effect on the quality of snacks. Characterization of snack from different blends of cereals with black gram was studied by Bhattacharya and Narasimha (1999). A traditional oriental snack food was made from 
blends of black gram with various cereals (rice, sorghum and wheat flour) at 25 and 40 per cent levels. Shrupalekar et al., (1972) studied the effect of water, common salt, carbonates and particle size of flour on the quality of plain black gram snacks. Common salt contributed to softness as well as desirable rolling property of the dough and diametrical expansion of snacks. Carbonates helped in obtaining fried snacks of uniform colour and desirable appearance, texture and taste. Black gram flour passing through 85 mesh sieve was found satisfactory for preparing snacks. Patil et al., (2001) studied the screening of different hydrocolloids for improving the quality of fried snack prepared from blackgram. The hydrocolloids chosen were guar gum, carraginan, carboxymethyl cellulose, hydroxypropylmethyl cellulose, gum tragacanth, gum karaya, gum ghatti and gum arable. Gum tragacanth at 0.5 per cent gave the best texture, measured as crispness using Steven's LFRA texturometer. Patil et al., (2005) indicate that a 2:1 combination of sodium carbonate and sodium bicarbonate was useful substitute for snacks, judged from the quality of fried snack and oil quality after frying. Drying techniques mostly rely on extending the keeping quality of the snacks by reducing the water activity (Scott, 1957). Frying is a cooking method that enhances the flavour, texture and appearance of food products (Anon, 1992). Modified atmosphere packaging (MAP) is the removal and/or replacement of the atmosphere surrounding the product before sealing in vapor-barrier materials (McMillin et al., 1999).

\section{Materials and Methods}

\section{Source of raw materials}

\section{Milk}

Milk for pursuing this study was procured from the Dairy Technology Section of Indian
Veterinary Research Institute, Izatnagar, Bareilly (U.P.). The milk procured was pasteurized one with combination of cow and buffalo milk as per daily production at dairy farm. Skim milk used in this study was prepared by an electrically operated cream separator (model- crema/90, Chadha Sales PVT LTD., Dairy Equipment Engineers, Delhi-110054, India). The particulars of skimmed milk used for the preparation of RTCMBS were as follows:

\section{Ingredients}

Rice (Oryza sativa) flour, Wheat (Triticum aestivum) flour, Black gram (Phaseolus munga Roxb), Green gram (Phaseolus auroux Rox), Gum tragacanth, Ascorbic acid, sodium carbonate, sodium bicarbonate, table salt and vegetable oil were purchased from the standard market of Bareilly, India.

\section{Chemicals}

All chemicals to be used will be of Analytical grade and obtained from standard firms (Qualigens, Hi Media, Polypharm, SRL etc.).

\section{Packaging material}

Low density polyethylene (LDPE) films (250 gauges) in natural colour were procured from the manufacturer, M/s Hitkari Industries Ltd., New Delhi, India for packing of the materials for storage studies.

Process for preparation of ready to cook milk based snacks "milk crisp"

\section{Preparation of skim milk coagulum (SMC)}

An electrically operated cream separator used for skimming of milk. Skim milk coagulum was prepared by following the coagulation procedure of Bhattacharya et al., (1971) with alteration made as per the requirements of the 
experiment in question. The cream separated "Skim milk" was heated to $85^{\circ} \mathrm{C}$ and cooled to $75^{\circ} \mathrm{C}$ for coagulation without holding. It was then coagulated adding $2 \%$ citric acid solution (120 $\mathrm{ml}$ per $\mathrm{kg}$ of milk). The coagulant solution was added slowly with constant stirring. After coagulation, the curd was transferred to muslin cloth and the whey was drained.

\section{Preparation of milk based snack}

Finely minced skim milk coagulum and adequate precooked (Pregelatinized: The flour was blended for 5 min with boiling water at a set hydration ratio of 2: 1 ) rice flour were mixed in home mixer (Lumix International, H.P., India) at high speed for 7 minutes. After adding wheat flour and salt, it was again mixed for 2 minutes. The kneaded batter/dough prepared by above process was put into a tray and placed in a steam chamber (inside pressure cooker) for 10 minute. Next it was taken out of the steam chamber and cooled to room temperature, shaped with the help of kitchen press or shaper in tape like or rectangular form (shape), size $(4-6 \mathrm{~cm})$ and thickness $(1.05 \mathrm{~mm})$ uniformly over the tray. The trays were placed in a hot air oven for drying at temperature of $45^{\circ} \mathrm{C}$ for 24 hours. Dried snack were cooled to room temperature, packed in low density polyethylene (LDPE) films (250 gauges), heat sealed and stored at ambient temperature $\left(37 \pm 2^{\circ} \mathrm{C}\right)$ till further use.

\section{Frying of milk based snack}

Refined oil was taken in the deep fat fryer [Frendz® (2 litre capacity)] and heated to the temperature of $190^{\circ} \mathrm{C}$. When temperature reached at $190^{\circ} \mathrm{C}$ as indicated by the thermostat, the dried milk based snacks were immersed into oil. The snacks were taken out in 10-15 seconds after they were puffed properly and excessive oil was wiped off with a tissue paper.

\section{Experimental design}

Preliminary trials conducted to standardise the formulation and processing conditions for the preparation of Milk Crisps. It is a Ready to Cook product, which can be consumed after frying. Milk crisp will be prepared by the incorporation of different levels of extenders i.e. Green gram and Black gram flour by replacing the amount of skim milk coagulum and coded as Treatment $\mathrm{B}$ and $\mathrm{A}$ respectively. Formulations of ready to cook milk based snack "milk crisp" as follows (Table I).

\section{Analytical procedures}

\section{Physico-chemical analysis}

\section{Product yield}

Weight of the batter prepared after adding water and the weight of the dried product after drying were recorded to calculate the product yield as follows:

$$
\text { Product yield }=\frac{\text { Weight of the dried snacks }}{\text { Weight of the batter }} \times 100
$$

\section{Expansion percentage}

Area of the raw snacks (before frying) was measured using graph paper. Then snacks were fried at $190^{\circ} \mathrm{C}$ for $10-15$ seconds. The area of fried snacks was also measured as before and expansion percentage was calculated as follows (Bhattacharya et al., 1999):

Expansion percentage $=$

Area of the snack chip after frying $\times 100$

Area of the snack chip before frying 


\section{Percentage oil uptake}

For measuring percentage oil uptake, weight of snacks was recorded before and after frying at $190^{\circ} \mathrm{C}$ for $10-15$ seconds in a deep fat fryer. After frying, excessive fat on the snacks was wiped off with a tissue paper before recording weight. Percentage oil uptake was recorded as follows (Pinthus et al., 1993):

Percentage Oil uptake $=$

Wt. of fried snacks $-\mathrm{Wt}$. of the dried snacks

Wt. of the dried snacks

\section{Warner-Bratzler Shear force value}

Shear force value of fried milk based snacks was determined using the texture analyser with a Warner -Bratzler blade attached to it (Smith et al., 1991). Milk based snack in the form of strip (approx. $1 \times 0.8 \mathrm{~cm}$ ) were taken for measuring shear force value. Each strip was placed in the shear force probe and shear force required to cut through the samples was recorded.

\section{Lovibond Tintometer Colour Units}

The colour of the milk based snacks was measured using a Lovibond Tintometer (Model F, Greenwich, U.K). Samples were finely ground in the home mixer, taken in the sample holder and secured against the viewing aperture. The sample colour was matched by adjusting the red (a) and yellow (b) units, while keeping the blue unit fixed at 0 . The corresponding colour units were recorded. The chroma values were determined by using the formula $(\mathrm{a} 2+\mathrm{b} 2) 1 / 2$ (Froehlich $e t$ al., 1983), where $\mathrm{a}=$ red unit, $\mathrm{b}=$ yellow unit.

\section{pH}

Ten grams of sample (after grinding in the home mixer for $1 \mathrm{~min}$.) was blended with 50 $\mathrm{ml}$ of distilled water for $1 \mathrm{~min}$. using an Ultra Turrax tissue homogenizer (Model T25, Janke and Kenkel, IKA Labor Technik, Germany). The $\mathrm{pH}$ of the homogenate was recorded (Trout et al., 1992) by immersing a combined glass electrode of a digital $\mathrm{pH}$ meter (Eutech Instruments, $\mathrm{pH}$ Tutor).

\section{Thiobarbituric acid reacting substances (TBARS) number}

The TBARS number of samples was determined by using the distillation method described by Tarladgis et al., (1960) and was expressed as $\mathrm{mg}$ malonaldehyde $/ \mathrm{kg}$ of sample.

\section{Proximate composition}

Moisture, crude fat, protein and ash contents of RTCMBS were determined by procedures prescribed by Association of Official Analytical Chemists (AOAC, 1995) using hot air oven, Soxhlet apparatus, Kjeldhal apparatus and Muffle furnace, respectively. Total carbohydrate determined by difference method (Pearson, 1976). Gross Energy calculated by using bomb calorimeter.

\section{Sensory evaluation}

Sensory evaluation of dehydrated meat rings was conducted using an eight point descriptive scale (Keeton, 1983) with slight modifications, where $8=$ excellent and $1=$ extremely poor. The experienced panel consisting of scientists and post graduate students of the Division of Livestock Products Technology, IVRI, Izatnagar, evaluated the samples, and all the analyses were conducted in triplicate. Sensory evaluation was done at $25{ }^{\circ} \mathrm{C}$ and $60 \%$ relative humidity. The panelists were briefed with the nature of the experiments without disclosing the identity of the samples and were requested to rate them on an eight point descriptive scale on the sensory evaluation pro-forma for different 
attributes. Water was provided to rinse the mouth between tasting of each sample. The panelists evaluated the samples for attributes such as appearance/ colour, flavour, texture, crispness, milk flavor intensity, after taste and overall acceptability.

\section{Statistical analysis}

All the data were expressed as mean \pm standard error of mean calculated from three independent experiments. The data were analyzed by SPSS statistical software package using standard procedures (Snedecor and Cochran, 1995). Duncan's multiple range tests was used to determine significant difference among means for different treatments.

\section{Results and Discussion}

\section{Comparison of control and selected treatment for physico-chemical characteristics}

Mean \pm SE values of physico-chemical properties of RTCMBS from control and selected treatments are presented in Table II.

\section{pH}

The values of $\mathrm{pH}$ ranged from $5.21 \pm 0.02$ for control to for 5.28 \pm 0.07 Treatment B. Control had slightly lower value for $\mathrm{pH}$ compared to treatments due to more amount of SMC. However, there was no significant $(\mathrm{P}>0.05)$ difference among them. Treatment $B$ had more $\mathrm{Ph}$ than control and treatment $\mathrm{A}$, might be due to lower SMC in its formulation. This lower value $\mathrm{pH}(<5.5)$ due to ascorbic acid addition at $0.5-1.0$ per cent markedly decreased the browning (Srinivasan, 2000).

\section{Yield percentage}

Values for yield percentage ranged from $35.93 \pm 0.90 \%$ for control to $42.50 \pm 1.32 \%$ for treatment B. Yield percentage for treatment B was significantly higher $(\mathrm{P}<0.01)$ when compared to others because batter preparation loss is very less. However control showed fewer yields even had high SMC contents, exhibited higher loss during batter preparation.

\section{Expansion percentage}

Expansion is an important physical attribute for the fried snacks that greatly affects consumer acceptability. Expansion percentage values ranged from $100.37 \pm 3.78 \%$ for control to $168.70 \pm 11.62 \%$ for treatment B. Expansion percentage was significantly $(\mathrm{P}<0.01)$ higher for treatment $\mathrm{B}$ than treatment $\mathrm{A}$ and control due to lower protein content and shear force value. According to Yohii and Arisaka (1994), protein reduces the expansion of amylopectin in rice starch during frying and causes reduction in the expansion ratio.

Although there was no significant difference for expansion percentage between treatment $A$ and control, the treatment having extender B (treatment B) resulted higher expansion percentage as compared to those having extender A (treatment A). This might be due to the difference in the properties of starch (amount of amylopectin), level of protein and shear force value. Due to high amount of amylopectin, the rice crackers could expand readily to produce a porous structure during frying. Protein reduced expansion of amylopectin, which resulted in decreased amount of pores in the fried rice crackers during frying (Yohii andArisaka, 1994).

Martinez- Serna et al., (1990) and Onwulata et al., $(1998,2001)$ investigated the effects of whey protein concentrate and isolate on the extrusion of corn and rice starch and reported a reduction in expansion at higher concentrations of protein. The rapid increase in volume of water during evaporation also causes expansion of fried food (Rossell, 
2001). Lower shear force value normally indicates lower bulk density and high expansion ratio (Park et al., 1993). The amount of moisture present in the mix directly affects the composition of product as well as expansion ratio, bulk density and shear force value (Conway, 1971; Park et al., 1993). Chandrasekhar (1989) reported decrease in hardness with increase in expansion ratio in case of rice puffing which was again observed to be a function of temperature, time, moisture content and air velocity. Suknark et al., (1998) observed that extrudates prepared from peanut flour and starches having low moisture content gave low shear strength as lower levels of moisture content provided lower product density, higher expansion and thinner cell walls which reduced the force necessary for shearing the extrudate.

\section{Percentage oil uptake}

The value for percentage oil uptake of fried RTCMBS was lowest for control i.e. $21.82 \pm 2.96 \%$ and highest for Treatment B i.e. $24.48 \pm 0.65 \%$. Control had significantly ( $\mathrm{P}>$ $0.05)$ lower oil uptake than treatment $B$ due to higher in initial moisture content leads to crust formation, higher in protein content. Yohii and Arisaka (1994) studied that less amount of oil penetration in the rice cracker with larger protein content. It was significantly higher $(P<0.05)$ for Treatment $\mathrm{B}$ than treatments $\mathrm{A}$ and control because of lower protein content, lower initial moisture and surface roughness. Initial moisture content of product affected oil absorption as well as microstructure of fried products (Aguilera, 2000). For frying processing, this involves loss of water from the food and the formation of a crust, which acts as a barrier to reduce the oil uptake. Besides, the crust formation might prevent the inside water from escaping to the outside and consequently preventing further oil uptake by rice crackers (Rossell, 2001). Certainly, surface roughness is a key factor in oil absorption, but other food-related properties, such as the microstructure of the crust, may explain differences between product categories (Moreno et al., 2010).

Many factors have been reported as affecting oil uptake, including oil quality, frying temperature and duration, the product's shape, its moisture, solids, fat or protein contents and porosity, pre-frying treatments (drying, blanching) and coating, among others (Pinthus et al., 1993). It is generally agreed that the oil content in a product increases with frying time. Most of the food products have an optimum cooking time and temperature (Rossell, 2001). If the frying time exceeds the optimum time, the finished product tend to have higher oil content (Esturk et al., 2000; Kayacier and Singh, 1999), as the oil adhering to the surface of the product is drawn into its pore structure. A possible reason for the reduction in the oil content during frying due to pre-fry drying could be the compactness of the material matrix (reduced porosity) or increase in the solid content.

\section{Shear force value of dried snack}

Shear force values ranged from $3.31 \pm 0.34$ (Treatment B) to $4.14 \pm 0.43$ (control). There was no significant $(\mathrm{P}>0.05)$ difference in the shear force values of control and treatments. In addition, control had higher value than Treatment A and B attributed to its higher moisture contents and lower fat: protein ratio (Mittal and Usborne 1986). Suknark et al., (1998) observe that shear strength in extrudates prepared from peanut flour and starches was lower when moisture content was lower. The amount of moisture present in the mix directly affects the composition of product as well as expansion ratio, bulk density and shear force value (Conway 1971; Park et al., 1993). 


\section{Chroma / yellowness/colour value of dried snack}

Redness value was zero for control as well as Treatments therefore chroma value similar to yellowness value. Yellowness was also lowest for control $(0.0037 \pm 0.0012)$ and highest for Treatment B $(0.1167 \pm 0.0033)$. . The values for Yellowness/chroma were significantly higher $(\mathrm{P}<0.01)$ for treatments than control. This could be attributed to the incorporation extenders. Singh et al., (1996) analyzed that blending of green gram flour in wheat or rice flour, resulted in darker colour snack. However, there was no significant difference in the $(\mathrm{P}>0.05)$ chroma values of among treatments. Maillard reaction, a nonenzymatic browning reaction between amino acids and reducing sugars, is the primary color formation reaction (Baik and Mittal, 2003; Moyano et al., 2002).

\section{Proximate analysis}

Moisture content of dried snacks ranged from $10.26 \pm 0.28 \%$ for control to $7.50 \pm 0.07 \%$ for Treatment B. There was highly significant ( $P>0.01)$ difference in moisture content of control and treatments. However, comparatively higher moisture in control than treatments could be attributed to the water binding/ holding capacity of milk proteins. The protein content values in dried snacks ranged from $25.17 \pm 0.96$ for Treatment $\mathrm{B}$ to $28.8 \pm 0.69$ for control. There was highly significant $(\mathrm{P}<0.01)$ difference in the protein content of control and treatments. Treatment B had significantly lower value for protein compared to other, which is due to the lower amount of SMC. However, there was also significant $(\mathrm{P}>0.05)$ difference between treatments due to difference in SMC content and type of extender in their formulation (Bravo et al., 1999), indicate extender had significant effect on protein percentage. Highest value for fat content of dried snacks was for control i.e. $0.76 \pm 0.04 \%$ and lowest value for treatment B i.e. $0.60 \pm 0.03 \%$. Treatments had significantly ( $\mathrm{P}<0.05)$ lower values for fat than control. Control had higher value for fat as it mainly contained SMC, which are more in fat content. Incorporation of extenders in treatments could be the reason for low fat content of treatments. Fat: protein value was significantly higher for treatment $B$ as compare to control and treatment A. Therefore treatment A showed higher texture, flavour and overall acceptability score on sensory evaluation. According to Mittal and Usborne (1986), fat-protein ratio was negatively correlated with acceptable colour, brittleness, gumminess, chewiness, elasticity, hardness and shear force but positively correlated with texture, flavour and overall acceptability of snack foods. Values for ash content of dried snacks ranged from $3.07 \pm 0.06 \%$ for treatment $\mathrm{A}$ to $3.53 \pm 0.20 \%$ for control. There was significant $(\mathrm{P}>0.05)$ difference in ash content of dried snacks between control and treatments. It might be due to different in their composition and extenders used. The carbohydrate \% values in dried snacks ranged from $56.21 \pm 0.56$ for control to $60.87 \pm 0.63$ for treatment B. There was significant $(\mathrm{p}<0.05)$ difference in the carbohydrate content of control and treatments. Control had significantly lower value for carbohydrate compared to treatments, which is due to the higher SMC and absence of extender. However, there was no significant $(p>0.05)$ difference between treatments due to similar extender composition (Bravo et al., 1999).

Gross energy of control had significantly higher value as compare to treatments, attributed to its high protein contents. However among treatments there was no significant difference, more protein percentage in treatment $\mathrm{A}$ compensated by high carbohydrate content of treatment B when gross energy was calculated. 
Comparison of control and selected treatment for sensory properties

Mean \pm SE values of sensory evaluation of fried RTCMBS from control and other treatments are presented in Table III.

\section{Appearance}

There was significant $(\mathrm{P}<0.05)$ difference in appearance/colour scores among different treatments. The appearance/colour scores for all 3 treatments were rated as good to very good. Treatments B had highest score $(7.08 \pm 0.06)$ whereas control had the lowest $(6.87 \pm 0.09)$, indicating significant $(\mathrm{P}<0.05)$ effect of level of SMC as well as extenders on the appearance of fried snacks.

\section{Flavour}

The flavour scores of different treatments ranged from $6.91 \pm 0.06$ for treatment $B$ to $7.06 \pm 0.09$ for control due to difference in SMC level. There was no significant $(\mathrm{P}>$ $0.05)$ difference in flavour scores among different treatments.

Flavour scores for treatment B had higher than treatment $\mathrm{A}$, indicating that extender had some effect on the flavour. However, there was no clear-cut significant difference ( $P$ $>0.05$ ) between treatments having different combination of extenders. From this, it is evident that there was no significant effect of different extender combinations on the flavour of milk based snacks.

\section{Texture}

There was no significant $(\mathrm{P}>0.05)$ difference in texture scores among different treatments. The highest score was for treatment $\mathrm{B}$ $(7.05 \pm 0.12)$ and the lowest was for control (6.78 \pm 0.10$)$, indicating higher level of SMC decline texture score. However, level of SMC and extenders had no significant $(\mathrm{P}<0.05)$ effect on the texture.

\section{Crispness}

The highest score was for treatment B $(7.27 \pm 0.13)$ and the lowest was for control $(6.94 \pm 0.11)$. Control had significantly lower $(\mathrm{P}>0.05)$ values than other treatments. Therefore, level of SMC had no significant $(\mathrm{P}>0.05)$ effect on the crispness. In addition, there was significant difference $(\mathrm{P}>0.05)$ between treatments having different combinations of extenders attributed to ingredients formulation, structural properties of extenders and expansion of RTCMBS.

Crispness is a unique characteristic and an important parameter to be controlled in deepfat fried products (Pedreschi and Moyano, 2005; Thanatuksorn et al., 2007). Many researchers agree that crispness results from structural properties of food (Barrett et al., 1994; Barrett and Peleg, 1992; Bouvier et al., 1997; Mohamed et al., 1982 and Stanley and Tung, 1976). Crispness is typically a textural parameter for fried products which depends upon the ingredients, formulation (proper balance among ingredients), and processes (mixing and frying) (Chang, 1993). In general the crispness of extruded products is directly correlated with acceptability of product and expansion is a major factor which contributes towards crispness (Peri et al., 1983).

\section{Milk flavour intensity}

The scores for milk flavour intensity ranged from 6.96 \pm 0.11 (treatment B) to $7.07 \pm 0.08$ (control). However, there was no significant $(\mathrm{P}>0.05)$ difference in scores of different treatments. Thus, the level of SMC and specific extender had some effect on the milk flavour intensity but not significantly ( $P$ $>0.05$ ). 


\section{After-taste}

There was significant $(\mathrm{P}<0.05)$ difference in after taste scores among different treatments which ranged from $6.88 \pm 0.08$ (control) to $7.23 \pm 0.10$ (treatments B). It might be due to more expanded/ crisp product gave more taste intensity in mouth.

\section{Overall acceptability}

Overall acceptability score was highest for treatment B $(7.00 \pm 0.05)$ and lowest for control (6.87 \pm 0.08$)$. Overall acceptability scores for treatment $\mathrm{A}$ and control were significantly $(\mathrm{P}>0.05)$ lower than treatment $\mathrm{B}$. It might be due to more crispness, expansion and higher fat: protein ratio of treatment $\mathrm{B}$.

Table.1

\begin{tabular}{cccccc}
\hline ph & Fat & SNF & Density & Protein & Lactose \\
\hline $6.67 \pm 0.05$ & $0.63 \pm 0.08$ & $8.09 \pm 0.12$ & $31.3 \pm 2.35$ & $2.95 \pm 0.31$ & $4.48 \pm 0.32$ \\
\hline \multicolumn{4}{r}{ (Result obtained from Ultrasonic Milk Analyzer Master classic LM2) }
\end{tabular}

Table.1 Formulations of ready to cook milk based snack "milk crisp"

\begin{tabular}{lccc} 
Treatment No. & Control & Treatment A & Treatment B \\
\hline Skim milk coagulum $(\%)$ & 55 & 50 & 45 \\
Rice flour $(\%)$ & 35 & 35 & 35 \\
Wheat flour $(\%)$ & 10 & 10 & 10 \\
Black gram flour (\%) & - & 5 & - \\
Green gram flour $(\%)$ & - & - & 10 \\
Gum tragacanth (g/100gm of batter) & 0.5 & 0.5 & 0.5 \\
Ascorbic acid (g/100gm of batter) & 0.75 & 0.75 & 0.75 \\
Table Salt (g/100gm of batter) & 0.75 & 0.75 & 0.75 \\
2:1 combination of sodium carbonate & 0.25 & 0.25 & 0.25 \\
and sodium bicarbonate (g/100gm of batter) & & &
\end{tabular}


Table.2 Comparison of control and selected treatment for physico-chemical characteristics $($ mean $\pm \mathrm{SE})$

\begin{tabular}{|c|c|c|c|}
\hline \multirow[t]{2}{*}{ Parameters } & \multirow[t]{2}{*}{ Control } & \multicolumn{2}{|c|}{ Treatments } \\
\hline & & A & $\mathrm{B}$ \\
\hline $\mathrm{pH}$ & $5.21 \pm 0.02$ & $5.24 \pm 0.09$ & $5.28 \pm 0.07$ \\
\hline Yield percentage & $35.93 \pm 0.90^{\mathrm{b}}$ & $37.72 \pm 0.61^{\mathrm{b}}$ & $42.50 \pm 1.32^{\mathrm{a}}$ \\
\hline Expansion percentage & $100.37 \pm 3.78^{b}$ & $118.10 \pm 4.15^{\mathrm{b}}$ & $168.70 \pm 11.62^{\mathrm{a}}$ \\
\hline Percentage Oil Uptake & $21.82 \pm 2.96^{\mathrm{b}}$ & $22.66 \pm 1.27^{\mathrm{b}}$ & $24.48 \pm 0.65^{\mathrm{a}}$ \\
\hline Shear force value $(\mathrm{N})$ & $4.14 \pm 0.43$ & $3.84 \pm 0.77$ & $3.31 \pm 0.34$ \\
\hline Colour value & $0.0037 \pm 0.0012^{b}$ & $0.1100 \pm 0.0000^{\mathrm{a}}$ & $0.1167 \pm 0.0033^{\mathrm{a}}$ \\
\hline Moisture \% & $10.26 \pm 0.28^{\mathrm{a}}$ & $7.66 \pm 0.16^{b}$ & $7.50 \pm 0.07^{\mathrm{b}}$ \\
\hline Protein \% & $28.69 \pm 0.60^{\mathrm{a}}$ & $27.81 \pm 0.04^{\mathrm{a}}$ & $25.17 \pm 0.96^{\mathrm{b}}$ \\
\hline Fat $\%$ & $0.76 \pm 0.04^{\mathrm{a}}$ & $0.67 \pm 0.03^{b}$ & $0.61 \pm 0.05^{b}$ \\
\hline Fat/ protein ratio & $0.0240 \pm 0.003^{c}$ & $0.0251 \pm 0.004^{b}$ & $0.0265 \pm 0.002^{\mathrm{a}}$ \\
\hline Ash \% & $3.53 \pm 0.20^{\mathrm{a}}$ & $3.07 \pm 0.06^{b}$ & $3.46 \pm 0.06^{\mathrm{ab}}$ \\
\hline Carbohydrate $\%$ & $56.21 \pm 0.56^{\mathrm{b}}$ & $59.85 \pm 0.98^{\mathrm{a}}$ & $60.87 \pm 0.63^{\mathrm{a}}$ \\
\hline Gross energy (Kcal/gm) & $361.56 \pm 4.91^{\mathrm{a}}$ & $345.63 \pm 3.36^{\mathrm{b}}$ & $345.57 \pm 6.89^{b}$ \\
\hline
\end{tabular}

Mean with different superscripts (row wise) differ significantly $(\mathrm{p}<0.05)$

$\mathrm{n}=6$ for $\mathrm{ph}$, moisture $\%$, protein $\%$, fat $\%$, fat: protein, ash $\%$, carbohydrate $\%$ and gross energy, $\mathrm{n}=9$ for expansion percentage and percentage oil uptake, colour value, $n=3$ for yield percentage and $n=30$ for shear force value 
Table.3 Comparison of control and selected treatment for sensory properties (mean $\pm \mathrm{SE}$ )

Sensory attribute

Treatments

Control

Apperance/Colour
Flavour

$7.06 \pm 0.09$
$6.87 \pm 0.09^{\mathrm{b}}$

Texture

$6.78 \pm 0.10$

Crispiness

After-taste

Milk flavour Intensity

Overall acceptability

$$
6.94 \pm 0.11^{\mathrm{c}}
$$$$
6.88 \pm 0.08^{\mathrm{b}}
$$

$7.07 \pm 0.08$

$6.87 \pm 0.08^{\mathrm{b}}$
A

$7.03 \pm 0.02^{\mathrm{ab}}$

$6.91 \pm 0.06$

$6.96 \pm 0.13$

$7.17 \pm 0.10^{\mathrm{b}}$

$7.11 \pm 0.16^{\mathrm{ab}}$

$7.00 \pm 0.13$

$6.88 \pm 0.08^{\mathrm{b}}$
B

$7.08 \pm 0.067^{\mathrm{a}}$

$7.00 \pm 0.05$

$7.05 \pm 0.12$

$7.27 \pm 0.13^{\mathrm{a}}$

$7.23 \pm 0.10^{\mathrm{a}}$

$6.96 \pm 0.11$

$7.00 \pm 0.05^{\mathrm{a}}$

$\mathrm{n}=21$

Mean with different superscripts (row wise) differ significantly $(\mathrm{P}<0.05)$

Score on 8 point Descriptive Scale, $8=$ Excellent, $1=$ extremely poor

In general the crispness of extruded products is directly correlated with acceptability of product and expansion is a major factor which contributes towards crispness (Peri et al., 1983). In addition, although treatments having higher SMC level scored lower for overall acceptability. Therefore, we can conclude that a lower level of SMC had a significant effect on overall acceptability. It is the combination of extenders and SMC level, which determined the score.

According to Mittal and Usborne (1986), fatprotein ratio was negatively correlated with acceptable colour, brittleness, gumminess, chewiness, elasticity, hardness and shear force but positively correlated with texture, flavour and overall acceptability of snack foods. In such a food where expansion is desired and puffed products are expected, texture is the major importance, with crispness being one of the most important attribute (Pamies et al., 2000). The combination of convective airdrying and deep fat frying can result in a product with less fat uptake during frying with acceptable sensory attributes, which in turn result in a low-fat and economical product (Debnath et al., 2003).

In conclusion, a process was standardised for the manufacture of ready to cook milk based snack using skim milk coagulum. To simulate the expansion ratio and sensory attribute of the conventional product, addition of bulking agents such as Gum tragacanth, ascorbic acid, table salt and 2:1 combination of sodium 
carbonate and sodium bicarbonate were also optimised. Skim milk coagulum was successfully replaced (5 to $10 \%$ ) with extender like black gram and green gram flours for the manufacture of extended milk crisp. The $\mathrm{pH}$ of prepared ready to cook milk based snack was almost acidic $(<\mathrm{pH} 5.5)$, and it was found most suitable to reduce the maillard reaction. As the level of skim milk coagulum decreases in products there protein, fat, gross energy and moisture content reduces but yield, ash and carbohydrate content increases. Moisture content of product directly related to its shear force value. Physio-chemical studies of green gram incorporated milk crisp samples revealed that its low moisture, protein and shear force value enhance expansion ratio and percentage oil uptake significantly. Improvement in the sensory attributes of milk crisp was noticed by addition of legume flours especially in case of green gram incorporation. Considering the significance of milk crisp as a dairy food, its production with legume flours could be highly beneficial for consumers who require/ desire such crispy snacks.

\section{References}

Abd -El-Salam, M. H., El-Shibiny, S. and Salem, A. (2009). Factors affecting the functional properties of whey protein products: A review. Food Rev Int. 25:251-270.

Aguilera, J. M. (2000). Microstructure and food product engineering. Food Technology. 54(11):56-65.

Anon. (1992). New specialty starches for manufacture of fruit preparations with high Brix values. DMZLebensmittelindustrie-und-Milchwirtschaft. 113(24):704-707.

AOAC. (1995). Official Method of Analysis. 16th edn. Association of Official Analytical Chemists. Washington D.C.

Baik, O. and Mittal, G. S. (2003). Kinetics of tofu color changes during deep-fat frying. LWT-Food Science and Technology. 36: 43-48.

Barrett, A. H. and Peleg, M. (1992). Extrudate Cell Structure-Texture Relationships. Journal of Food Science. 57(5): 12531257.

Barrett, A. H., Cardrello, A. V., Lesher, L. L. and Taub, I. A. (1994). Cellularity, Mechanical Failure, and Textural Perception of Corn Meal Extrudates. Journal of Texture Studies. 25 (1):7795.

Bhasin, N. R. (2010). From the president's desk. Indian Dairyman. 62:12-13.

Bhattacharya, D. C., Mathur, O. N., Srinivashan, M. P and Samlik, O. (1971). Studies on the methods of production and shelf life of paneer. Journal of food science and technology 8:117-120.

Bhattacharya, M., Hanna, M. A. and Kaufman, R. E. (1999). Textural properties of extruded plant protein blends. J. Food Sci., 51: 988-993.

Bhattacharya, S. and Narasimha, H. V. (1999). Characterization of papad from different blends of cereals with blackgram. J Food Qual. 22:157-166.

Bosse, A. and Boland, M. (2012). Dried beef industry profile. Available at http://www.

Agmrc.org/agmrc/commodity/livestock/ beef/driedbeefindustryprofile.htm.

Bouvier, J. M., Bonneville, R. and Goullieux, A. (1997). Instrumental methods for the measurement of extrudate crispness. Agro-Food Industry Hi-Technology 8:16-19.

Bravo, L., Siddhuraju, P. and Saura-Calixto, F. (1999). Composition of underexploited Indian pulsesComparison with common legumes. Food Chemistry 64: 185-192

Brower, A. (2002). The U.S. market for salted snacks. Packaged facts. Report ID: 


\section{LA728892.}

http://www.packagedfacts.com/SaltedSnacks-728892

Chandrasekhar, P. R. (1989). Some studies on heated air fluidized bed puffing characteristics of rice. Unpublished Ph.D. Thesis, PHTC, IIT, Kharagpur (W.B.) India.

Chang, C. N., Dus, S. and Kokini, J. L. (1993). Measurement and Interpretation of Batter Rheological Properties. In: (Kulp, K. Loewe, R. eds.) Batters and Breadings in food processing, AAAC, St. Paul, MN, pp 199-226.

Conway, H. F. (1971). Extrusion cooking of cereals and soybean. Part 1. Food Products and Development 5:14.

Debnath, S., Bhat, K. and Rastogi, N. (2003). Effect of pre-drying on kinetics of moisture loss and oil uptake during deep fat frying of chickpea flourbased snack food. Lebensmittel-Wissenschaft-undTechnologie 36:91-98.

Esturk, O., Kayacier, A. and Singh, R. K. (2000). Reduction of oil uptake in deep fried tortilla chips. Food Science and Technology International 6:425-431.

Froehlich, D. A., Gullet, E. A. and Usborne, W. R. (1983). Effect of nitrite and salt on the colour, flavour and overall acceptability of ham. Journal of Food Science 48:152-154.

Huang, D. P. (2000). New perspectives on starch and starch derivatives for snack applications. Cereal Food World 40: 528-533.

Kayacier, A. and Singh, R. K. (1999). Rheological properties of deep fried tortillas prepared with hydrocolloids. International Journal of Food Properties 2(2):185-193.

Keeton, J. T. (1983). Effect of fat and sodium chloride/phosphate levels on the chemical and sensory properties of pork patties. Journal of Food Science 48: 878-85.
Madureira, A. R., Tavares, T., Gomes, A. M., Pintado, E. M. and Malcata, X. M. (2010). Invited review: Physiological properties of bioactive peptides obtained from whey proteins. J. Dairy Sci. 93:437-455.

Martinez-Serna, M., Hawkes, J. and Villota, R. (1990). Extrusion of natural and modified whey proteins in starch-based systems. In: Press WEL.

McMillin, K. W., Huang, N. Y., Ho, C. P. and Smith, B. S. (1999). Quality and shelflife of meat in case-ready modified atmosphere packaging. In Y. L. Xiong, F. Shahidi, C. T. Ho (Ed.), Quality in muscle foods. New York: ACS Symposium Series, Plenum Publishing Corporation. pp. 73-93.

Mittal, G. S. and Usborne, W. R. (1986). Meat emulsion functionality related fat protein ratio and selected dairy and cereal products. Meat science 18: 1-21.

Mohamed, S. (1990). Factors affecting extrusion characteristics of expanded starch-based products. Journal of Food Processing and Preservation 14:437452.

Moreno, M. C., Brown, C. A. and Bouchon, P. (2010). Effect of food surface roughness on oil uptake by deep-fat fried products. Journal of Food Engineering 101:179-186.

Moyano, C. P., Rioseco, K. V. and Gonzalez, A. P. (2002). Kinetics of crust color changes during deep-fat frying of impregnated French fries. Journal of Food Engineering, 54: 249-255.

Onwulata, C. I., Smith, W. P., Konstance, P. R. and Holsinger, H. R. (2001). Incorporation of whey products in extruded corn, potato or rice snacks. Food Res. Int. 34: 679-687.

Onwulata, C. I., Konstance, P. R., Cooke, H. P. and Farrell, Jr. H. R. (2003). Functionality of extrusion-texturized whey proteins. J. Dairy Sci. 86: 3775- 
3782.

Onwulata, C. I., Konstance, P. R., Smith, P. W. and Holsinger, V. H. (1998). Physical properties of extruded products as affected by cheese whey. Journal of Food Science 63:814-818.

Pamies, B. V., Roudaut, G., Dacremont, C., Le Meste, M. and Mitchell, R. (2000). Understanding the texture of low moisture cereal products part I mechanical Nand sensory measurements of crispness. Journal of the Science of Food and Agriculture 80: 1679- 1685.

Park, J., Rhee, K. S, Kim, B. K. and Rhee, K. C. (1993). High Protein texturized Product of Defatted Soy Flour, Corn Starch and Beef: Shelf-Life, Physical and Sensory Properties. J. Food Sci. 58: 21-27.

Patil, S. J., Singhal, R. S. and Kulkami, P. R. (2001). Screening of different hydrocolloids for improving the quality of fried papads. Journal of Texture Studies 22(3): 125-128.

Patil, S. J., Singhal, R. S. and Kulkami, P. R. (2005). Studies of a 2:1 sodium carbonate: sodium bicarbonate mixture as a papad khar substitute for papad. Food Chemistry 91: 51 -56.

Pearson, D. (1976). The Dictionary of Nutrition and Food Technology. Fifth edition. Butter Worth Publisher London.

Pedreschi, F. and Moyano, P. (2005). Effect of pre-drying on texture and oil uptake of potato chips. LWT-Food Science and Technology 38(6): 599-604.

Peri, C., Barbieri, R. and Casiraghi, E. M. (1983). Physical, chemical and nutritional quality of extruded corn germ flour and milk protein blends. Journal of Food Technology 18: 43-52.

Pinthus, E. J., Fan, J. and Singh, R. P. (1993). Physicochemical changes in starch during deep fat frying of a molded corn starch patty. Journal of Food
Processing and Preservation 21: 443460.

Rossell, B. J. (2001). Factors affecting the quality of frying oils and fats: Improving quality. Cambridge UK: CRC Press. pp. 115-336.

Sawyer, L., Barlow, P. N., Boland, M. J., Creamer, L. K., Denton, H., Edwards, P. J. B., Holt, C., Jameson, G. B., Kontopidis, G., Norris, G. E., Uhrinova, S. and $\mathrm{Wu}, \mathrm{S}$. Y. (2002). Milk protein structure - What can it tell the dairy industry? International Dairy Journal, 12(4): 299-310.

Scott, W. J. (1957). Water relations of food spoilage microorganisms. Advances in Food Research 7:81-124.

Shurpalekar, S. R., Venkatesh, K. V. L. (1975). Studies on papad based on blends of blackgram with cereals, pulses and starches. J. Food Sci. Tech. 12: 3235 .

Shurpalekar, S. R., Prabhakar, J. V., Venkatesh, K. V. L., Vibhakar, S. and Amla, B. L. (1972). Some factors affecting the quality of blackgram (Phaseolus mungo) papads. J. Food Sci. Tech. 9: 26-29.

Singh, N., Bajwa, U. and Sekhon, K. S. (1996). Pasting and papad quality of rice, wheat and mung flour blends. Journal of Food Science and Technology 33: 224-228.

Singh, V. P., Sanyal, M. K., Dubey, P. C. and Mendiratta, S. K. (2011). Quality assessment of vacuum packaged chicken snacks stored at room temperature. J. Stored Prod. Postharvest Res. 2: 120-126.

Smith, G. L., Stadler, J. W., Keeton, J. T. and Papadopoulos, L. S. (1991). Evaluation of partially defatted chopped beef in fermented beef snack sausage. Journal of Food Science 56: 348-351.

Smithers, G. W. (2008). Whey and whey proteins-from 'gutter-to gold'. Int. 
Dairy J. 18:695-704.

Snedecor, G. W. and Cochran, W. G. (1995). Statistical methods, $8^{\text {th }}$ Ed. IOWA State University Press Ames IOWA.

Srinivasan, S. (2000). Mini papad containing cheese powder and novelty snack food. J. Food Sci. Nutr 51: 147-215.

Stanley, D. W. and Tung, M. A. (1976). Microstructure of food and its relationship to texture. In J. M. DeMan; P. W. Voisey; V. F. Rasper; D. W. Stanley (ed.), Rheology and Texture in Food Quality, AVI Publishing Co. Inc. Westport CT.

Suknark, K., Phillips, R. D. and Chinnan, M. S. (1998). Physical properties of directly expanded extrudates formulated from partially defatted peanut flour and different types of starch. Food Research International 30:515-583.

Tarladgis, B. G., Watts, B. M., Younathan, M. T. and Dugan, L. R. (1960). A distillation method for the quantitative determination of malonaldehyde in rancid foods. Journal of American Oil Chemist Society 37:403-06.

Tettweiler, P. (1991). Snack foods worldwide.
Food Technol 45: 58-62.

Thanatuksorn, P., Kajiwara, K. and Suzuki, T. (2007). Characterization of deep-fat frying in a wheat flour-water mixture model using a state diagram. Journal of the Science of Food and Agriculture 87(14): 2648-2656.

Trater, A. M., Alavi, S. and Rizvi, S. S. H. (2005). Use of non-invasive X-ray microtomography for characterizing microstructure of extruded biopolymer foams. Food Res. Int 38: 709-719.

Trout, E. S., Hunt, M. C., Johnson, D. E., Claus, J. R., Kastner, C. L. and Kropt, D. H. (1992). Characteristics of low fat ground beef containing texture modifying ingredients. Journal of Food Science 57(1):19-24.

Yohii, Y. and Arisaka, M. (1994). Relationships between physicochemical properties of nonglutinous rice and degree of expansion of rice cracker. Journal of the Japanese Society for Food Science and Technology - Nippon Shokuhin Kagaku Kogaku Kaishi 41(11):747-754.

\section{How to cite this article:}

Bhujendra Soni, Geeta Chauhan, S.K. Mendiratta and Subhashis Mohapatra. 2020. Physicochemical and Sensory Properties of Ready-To-Cook Milk based Snack "Milk Crisp". Int.J.Curr.Microbiol.App.Sci. 9(07): 3116-3131. doi: https://doi.org/10.20546/ijcmas.2020.907.367 